\title{
Fish and rice flourish together in paddies
}

\section{Farming two species at once promises double the income, study suggests.}

Jan Piotrowski

17 November 2011

\section{An article from SciDev.Net.}

A traditional farming technique that cultivates rice and fish side-by-side could help small farmers earn more money from their crops and reduce the impact on the environment, according to a study.

When fish were introduced into flooded paddy fields, farmers were able to grow the same amount of grain as in conventional rice monocultures - but with more than two-thirds less pesticide and a quarter less fertiliser, found a six-year long study conducted in China.

These rice-fish co-cultures could lessen the environmental impact of agricultural chemicals and help make rice farming more profitable, said the study, published in the Proceedings of the National Academy of Science this week ${ }^{1}$.

"In areas where land and water are limited for developing both rice and fish production, it is important to conduct RF [rice-fish co-culture]," Xin Chen, lead author of the study and a professor at Zhejiang University, China, told SciDev.Net. She added that the technique should be combined with modern techniques such as irrigation, and the use of machinery.

The fish used in the study were an indigenous carp species that is considered a delicacy, so farmers could sell them. They could also make large savings on fertilisers and

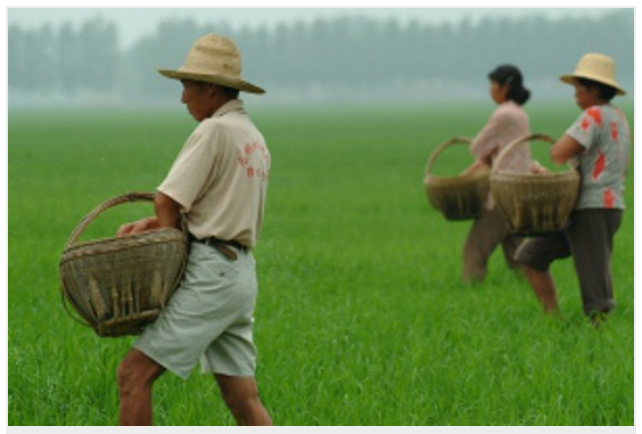

Fickr/IRRI Images

Fish minimized the need for fertilizer. pesticides, which typically represent 60-70 per cent of the total cost of rice production.

Fish significantly lower the risk of rice sheath blast disease and reduce the amount of weeds and harmful pests such as the rice planthopper. This invasive insect has the potential to devastate entire rice fields - an outbreak in Thailand last year destroyed four per cent of the country's harvest.

By regulating the amount of nitrogen in the ecosystem, the practice also minimised the need for applying fertiliser.

Rice plants also provided shade, thus keeping the water cool and allowing fish to remain active even during the hottest months. And insects attracted to the plants provided extra food for the fish.

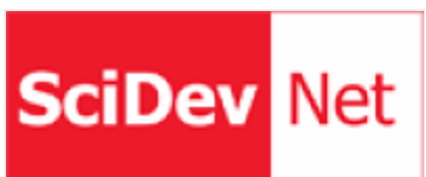

More from SciDev.Net.
Zainul Abedin, a farming systems specialist at the International Rice Research Institute, in the Philippines, said: "This is an extremely useful tool for poverty reduction and food security that can be used across tropical regions."

The practice can generate twice as much income compared with growing just rice, because of refinements of the thousand year-old technique, made possible by new research, he added. The findings reveal how 
the system works, hence making it possible to improve it.

Paul Kiepe, the Africa Rice Center's representative for East and Southern Africa told SciDev.Net: "As fish catches are becoming smaller, [this approach] will be increasingly important for ensuring that food production provides people with enough protein".

But Kiepe stressed that many farmers do not have the right knowledge and tools to make the system work yet.

Nature I doi:10.1038/nature.2011.9390

This article was first published by SciDev.Net on 17 November, 2011.

\section{References}

1. Xie, J. et al. Proc. Natl Acad. Sci. USA http://dx.doi.org/10.1073/pnas.1111043108 (2011). 